\title{
Effects of Stand Structure on Stem and Crown Biomass
}

\author{
Ana Cristina Gonçalves* \\ Department of Rural Engineering, Évora University, Portugal
}

Submission: January 02, 2018; Published: May 14, 2018

"Corresponding author: Ana Cristina Gonçalves, Department of Rural Engineering, School of Sciences and Technology, Institute of Agrarian and Environmental Environmental Sciences (ICAAM), Institute of Advanced Research and Training, University of Évora, Apartado 94, 7002-544 Évora, Portugal, Tel: +351266760800; Fax: +351266760911, E-mail: acag@uevora.pt

\begin{abstract}
Above ground biomass can be divided in two broad classes, according to its potential use: stem biomass used mainly for timber; and crown biomass used either for bio energy or to maintain and improve ecosystem services, in particular stand and site sustainability and fertility. The aim of this study is to evaluate the differences and similarities of stem and crown biomass in forest stands as function of species, composition (pure $v s$ mixed), structure (even-aged $v s$ multiaged) and the stage of development (young vs adult). The analysis was carried out for eight species in 255 plots, in Portugal. The results revealed stem and crown biomass proportion depends on the tree species ecological characteristics, especially if trees are in free growth. Stem biomass proportion tends to be higher in stands managed for timber regardless composition or structure while crown biomass is higher in stands managed as agro forestry systems.
\end{abstract}

Keywords: Structure; Composition; Stage of development; Species; Statistical analysis

Abbreviations: Qr: Quercus Rotundifolia; Qs: Quercus Suber; Pp: Pinus Pinea; Ppi: Pinus Pinaster; Cs: Castanea Sativa; Qru: Quercus Rubra; Bc: Betula Celtiberica; PE: Pure Even-Aged; PM: Pure Multi Aged; ME: Mixed Even-Aged; MM: Mixed Multi Aged; QRS: Quercus Suber; SP: Mixed of Pinus Pinea; SPP: Pinus Pinaster; PCR: Quercus Robur; RRB: Betula Celtiberica

\section{Introduction}

From late $20^{\text {th }}$ century onwards due to the need to evaluate carbon stocks, carbon sequestration and losses, as well as to estimate the biomass for energy, two main methods were used $[1,2]$ the direct and the indirect. The indirect method, the most frequently used, is mathematical functions, with one or more dendrometric variables at tree level (diameter at breast height and total height) as explanatory variables. The functions are species and site-specific, due to the development behaviour of each species, which is also related with the site quality. This results in a wide number of functions [3-6]. Most of the allometric biomass functions per species are developed per component. While functions are always developed for stem, in which regards the other components some are developed for branches or leaves, whereas others aggregate the latter components in a class, the crown. Above-ground biomass is the sum of the biomass of all components. Thus due to their formulation it is possible to divide it in two broad classes; stem and crown. These classes can be related to of each component utilisation; stem for timber and crown either for bioenergy or to remain in the stand to maintain and/or improve the stand and site productivity. The maintenance of biomass in the forest stand, especially the crown components, is suggested in the frame of sustainability of the site, stand and productivity [7], especially in the poorer sites, due to the amounts of nutrients in the crown [8]. Inversely stems are poor in nutrients thus their removal has less impact on the overall productivity and sustainability of the system [9].

Stand structure dynamics are determined by the interactions between the individual trees in a stand, which are also result of composition (pure vs mixed), structure (even-aged vs multiaged), stage of development (young vs adult) and spatial arrangement, both horizontal and vertical. The species ecological characteristics, namely genetic features, epinastic control and shade tolerance are also of primordial importance in the stand structure dynamics [10]. As a result, above ground biomass as well as the stem and crown biomass are influenced by the aforementioned tree and stand characteristics.

The goal of this study is the evaluation of the effect of species and stand structure on the partitioning of above-ground biomass in two broad classes, stem and crown. The specific objectives are the analysis of species ecological characteristics, stand composition (pure vs mixed), structure (even-aged vs multiaged) and stage of development (young vs adult) on the proportion of stem and crown biomass. 


\section{Material and Methods}

A set of 255 plots representative of the Portuguese forest area were selected (Table 1), to enable the characterisation of stem and crown biomass of different species and stand structures. In the field surveys, tree species were recorded and diameter at breast height, total height and height of the beginning of the crown were measured for all individuals with diameter at breast

Table 1: Plots location, species and number.

\begin{tabular}{|c|c|c|c|}
\hline Location & Central Coordinate & Species & Number \\
\hline \multirow{2}{*}{ Mora } & \multirow{2}{*}{$8^{\circ} 4^{\prime} 54^{\prime \prime} \mathrm{W}, 38^{\circ} 51^{\prime} 16^{\prime \prime} \mathrm{N}$} & Quercus rotundifolia & \multirow{2}{*}{44} \\
\hline & & Quercus suber & \\
\hline \multirow{2}{*}{ Alcácer do Sal } & \multirow{2}{*}{$8^{\circ} 40^{\prime} 28^{\prime \prime} \mathrm{W}, 38^{\circ} 27^{\prime} 46^{\prime \prime} \mathrm{N}$} & Quercus suber & \multirow{2}{*}{88} \\
\hline & & Pinus pinea & \\
\hline Pinheiro da Cruz & $38^{\circ} 16^{\prime} 56^{\prime \prime} \mathrm{N}, 8^{\circ} 45^{\prime} 19^{\prime \prime} \mathrm{W}$ & Pinus pinaster & 40 \\
\hline \multirow{3}{*}{ Lousã } & \multirow{3}{*}{$40^{\circ} 04^{\prime} 57^{\prime \prime} \mathrm{N}, 8^{\circ} 14^{\prime} 57^{\prime \prime} \mathrm{W}$} & Pinus pinaster & \multirow{3}{*}{32} \\
\hline & & Castanea sativa & \\
\hline & & Quercus robur & \\
\hline \multirow{3}{*}{ Arcos de Valdevez } & \multirow{3}{*}{$41^{\circ} 49^{\prime} 52^{\prime \prime} \mathrm{N}, 8^{\circ} 29^{\prime} 38^{\prime \prime} \mathrm{W}$} & Quercus robur & \multirow{3}{*}{9} \\
\hline & & Quercus rubra & \\
\hline & & Betula celtiberica & \\
\hline Montargil & $39^{\circ} 07^{\prime} 08^{\prime \prime} \mathrm{N}, 8^{\circ} 08^{\prime} 49^{\prime \prime} \mathrm{W}$ & Quercus suber & 6 \\
\hline Extremoz & $38^{\circ} 54^{\prime} 25^{\prime \prime} \mathrm{N}, 7^{\circ} 37^{\prime} 48^{\prime \prime} \mathrm{W}$ & Quercus suber & 6 \\
\hline Chamusca & $39^{\circ} 21^{\prime} 19^{\prime \prime} \mathrm{N}, 8^{\circ} 26^{\prime} 05^{\prime \prime} \mathrm{W}$ & Quercus suber & 6 \\
\hline \multirow{3}{*}{ Coruche } & \multirow{3}{*}{$39^{\circ} 06^{\prime} 27^{\prime \prime} \mathrm{N}, 8^{\circ} 21^{\prime} 48^{\prime \prime} \mathrm{W}$} & Quercus suber & \multirow{3}{*}{24} \\
\hline & & Pinus pinea & \\
\hline & & Pinus pinaster & \\
\hline
\end{tabular}

Stem and crown biomass were calculated with the allometric functions at tree level of Paulo and Tomé for Quercus rotundifolia and Quercus suber; of Correia et al. [13] for Pinus pinea; of IFN5 (2010) for Pinus pinaster, Castanea sativa and Betula celtiberica; height larger than $5 \mathrm{~cm}$ [11]. Plots' composition (pure vs mixed) was evaluated with four criteria stand classification [12], and structure (even-aged $v s$ multiaged) with diameter distributions using $2.5 \mathrm{~cm}$ classes. Two stages of development were considered, evaluated visually in the field, young, pure even-aged plots (24 plots) and adult (231 plots). Many plots included young and adult trees, though in a small number in the even-aged plots and larger in the multiaged plots.

Table 2: Stem and crown biomass allometric functions (where $d$ is the diameter at breast height (in $\mathrm{cm}$ ), $\mathrm{h}$ the total height (in $\mathrm{m}$ ), $\mathrm{c}$ is the circumference at breast height $c=\Pi \times \frac{d}{100}$ (in $\mathrm{m}$ ), Ic the crown length (in $\mathrm{m}$ ), ww stem biomass (in $\mathrm{kg}$ ), wc crown biomass (in $\mathrm{Kg}$ )).

\begin{tabular}{|c|c|}
\hline Species & Functions \\
\hline Quercus rotundifplia & $w w=0.164185 \times d^{2.0011002}$ \\
\hline Quercus suber & $w c=0.600169 \times d^{1.355957}+1.909152 \times d^{1.200354}$ \\
\hline Pinus pinea & $w w=18.85 \times c^{1.68} \times h^{0.95}$ \\
\hline Pinus pinaster & $w b r=0.0308 \times d^{2.75761} \times\left(\frac{h}{d}\right)^{-0.39381}+0.09980 \times d^{1.39252} \times\left(\frac{h}{d}\right)^{0.71962}$ \\
\hline Castanea sativa & $w c=184.94 \times c^{3.03}+22.27 \times c^{1.76} \times\left(\frac{h}{d}\right)^{-0.5}+8.08 \times c^{1.55} \times h^{0.47}$ \\
\hline & $w w=0.0146 \times d^{1.94687} \times h^{1.106577}$ \\
\hline & $w w=0.02 .44 \times d^{1.76603} \times h^{1.16402}$ \\
\hline
\end{tabular}




\begin{tabular}{|c|c|}
\hline Betula celtiberica & $w c=0.00440 \times d^{2} \times h+0.06574 \times d^{1.84096}$ \\
\hline Quercus robur & $w w=e^{\left(-3.323+\left(0.950 \times \ln \left(d^{2} \times h\right)\right)\right)}$ \\
\hline Quercus rubra & $w c=e^{\left(-14.246+\left(2.248 \times \ln \left(d^{2} \times h\right)\right)-0.01972 \times(l c \times h)\right)}$ \\
\hline
\end{tabular}

The stem and crown biomass was analysed considering species, structure and composition classes to enable further detail in the analysis. The species include Quercus rotundifolia $(\mathrm{Qr})$, Quercus suber (Qs), Pinus pinea (Pp), Pinus pinaster (Ppi), Castanea sativa (Cs), Quercus robur (Qro), Quercus rubra (Qru), Betula celtiberica $(\mathrm{Bc})$. The four structure classes are: pure evenaged (PE), pure multiaged (PM), mixed even-aged (ME) and mixed multiaged (MM); and the nine composition classes are: pure of Quercus rotundifolia (QR), pure of Quercus suber (QS), pure of Pinus pinea (PP), pure of Pinus pinaster (PPi), mixed of Quercus rotundifolia and Quercus suber (QRS), mixed of Quercus suber and Pinus pinea (SP), mixed of Quercus suber, Pinus pinea and Pinus pinaster (SPP), mixed of Pinus pinaster, Castanea sativa and Quercus robur (PCR) and mixed of Quercus robur, Quercus rubra and Betula celtiberica (RRB). Considering species have different behaviours the analysis was done with stem and crown biomass as a percent of the above-ground biomass. The comparison between the abovementioned species and stand structure classes was done using non parametric Wilcoxon test, as variables did not meet the normality criteria, evaluated with Shapiro-Wilk or Kolmogorov-Smirnoff test, depending on the size of the sample, and implemented in R Development Core Team.

\section{Results and Discussion}

The stem and crown biomass proportion show a wide variability. It is derived, at least partially, from the differences between species (Table 3), decreasing in general from species managed as agro forestry systems ( $\mathrm{Qr}, \mathrm{Qs}$ and $\mathrm{Pp}$ ) to those managed for timber (Cs, Qro, Qru, Be). This is probably related with the spatial arrangement of the trees. In the agro forestry systems stands have usually low density and trees are frequently isolated. However, the horizontal spatial distribution can be rather irregular with some trees isolated and others in clusters, which derives in a larger variability when compared with stands managed for timber where the horizontal spatial arrangement tends to be more regular. The proportion of stem biomass for adult trees is in average $64 \%$, varying between $17 \%$ and $94 \%$, with a coefficient of variation (CV) of $26 \%$, while young trees is $63 \%$, varying between $31 \%$ and $91 \%$, with $\mathrm{CV}$ of $23 \%$. The crown biomass for adult and young individuals has an average of $36 \%$ and $37 \%$, CV of $47 \%$ and $38 \%$, and ranges between $6 \%$ and $83 \%$, and 9 and $70 \%$, respectively. Noteworthy is the large variability of Pinus pinaster, which is a consequence of the different stand structures and stages of development. This species is present in pure, mixed, even-aged and multiaged the plots as well as young and adult plots. It is also noticeable for Quercus suber as they are present in young and adult plots and Pinus pinea as it is present in even-aged and multiaged plots (Table 3).

For all species crown biomass proportion when compared with stem biomass has a larger coefficient of variation (Table 3). Crown dimensions and consequently biomass are related to the species genetic characteristics, stage of development, epinastic control and shade tolerance. Different species have a wide range of crown shapes; Quercus spp., Castanea sativa and Pinus pinea have wide roundish branchy crowns, which are also related to their weak epinastic control. Inversely, Pinus pinaster and Betula celtiberica have narrow crowns and strong epinastic control $[16,17]$. The photo assimilates in young trees are primarily allocated to height growth while in adult trees are used predominantly for diameter growth, both stem and crown. Nevertheless, when available growing space is limiting, individual trees are not able to express their genetic characteristics due to the influence of the constellations of neighbours. Another determinant feature is the shade tolerance. Except for Castanea sativa and young Quercus spp., which show some shade tolerance, the other species and Quercus spp. adult individuals are shade intolerant [18-20], consequently stand structure and aerial growing space, determine their lateral development. Also, shading results in the death of the inferior part of the crown, especially in the shade intolerant species, reducing their length. The differences between species are corroborated by the significant differences among species by Wilcoxon test (all, $\mathrm{p}<0.05)$ Figure 1.

Table 3: Descriptive statistics of stem and crown biomass per species (where $\mathrm{m}$ is the mean, SD the standard deviation, min the minimum, max the maximum and $\mathrm{CV}$ the coefficient of variation).

\begin{tabular}{|c|c|c|c|c|c|c|c|c|c|c|}
\hline \multirow{2}{*}{ Species } & \multicolumn{5}{|c|}{ Stem Biomass } & \multicolumn{5}{|c|}{ Crown Biomass } \\
\hline & $\mathbf{m}$ & SD & $\min$ & $\max$ & CV & m & SD & $\min$ & $\max$ & CV \\
\hline Qr & 64.9 & 6 & 42.1 & 79 & 9.3 & 35.1 & 6 & 21 & 57.9 & 17.2 \\
\hline Qs & 57.9 & 8.1 & 41.9 & 83.6 & 13.9 & 42.1 & 8.1 & 16.4 & 58.1 & 19.1 \\
\hline $\mathrm{Pp}$ & 41.9 & 8 & 17.4 & 79.7 & 19 & 58.1 & 8 & 20.3 & 82.6 & 13.7 \\
\hline
\end{tabular}


JOJ Horticulture \& Arboriculture

\begin{tabular}{|c|c|c|c|c|c|c|c|c|c|c|}
\hline Ppi & 77.5 & 8.7 & 30.5 & 94.1 & 11.2 & 22.5 & 8.7 & 5.9 & 69.5 & 38.4 \\
\hline Cs & 83.4 & 2.3 & 77.1 & 90.9 & 2.7 & 16.6 & 2.3 & 9.1 & 22.9 & 13.8 \\
\hline Qro & 82.8 & 2.7 & 78.6 & 91.3 & 3.3 & 17.2 & 2.7 & 8.7 & 21.4 & 15.7 \\
\hline Qru & 80.4 & 1.2 & 78.2 & 86.8 & 1.5 & 19.6 & 1.2 & 13.2 & 21.8 & 6.1 \\
\hline Bc & 81.1 & 1 & 78.6 & 83.9 & 1.3 & 18.9 & 1 & 16.1 & 21.4 & 5.5 \\
\hline
\end{tabular}
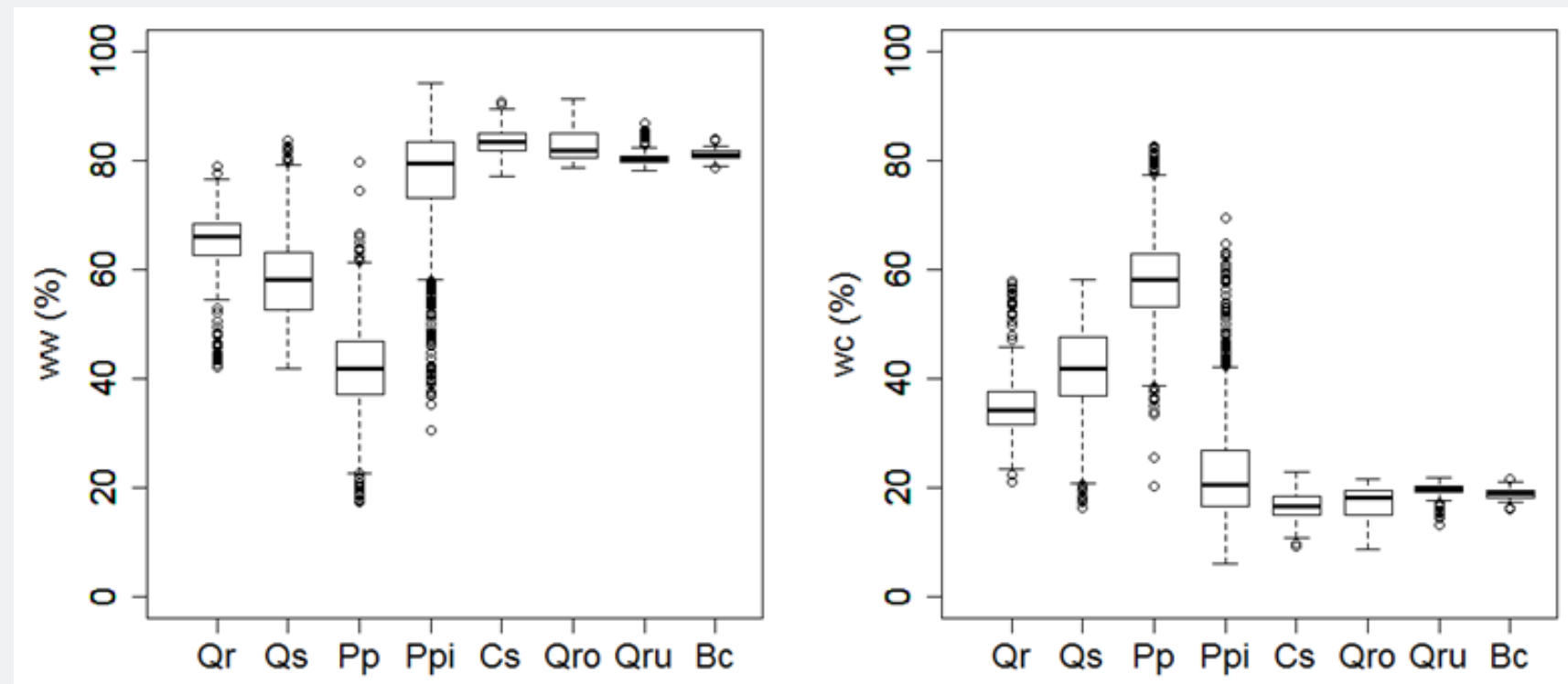

Figure 1: Boxplot of stem (ww) and crown (wc) biomass proportion per species.

The analysis per composition, structure and development stage classes of the plots show wider range for crown than for stem biomass proportion (Table 4). In general, variability of biomass increases from pure to mixed plots and from even-aged to multiaged plots, except for stem biomass that has a larger CV for pure than for mixed plots, reflecting the difference in the stage of development of the plots. When discriminating plots per structure classes (Figure 2a,c) variability increases from even-aged (PE, ME) to multiaged plots (PM, MM), explained by the number of species and their proportions per cohort [21]. PE plots dispersion is due to the stage of development of the plots.
Quercus suber and Pinus pinaster have a similar number of young (10, 10 respectively) and adult $(8,11$, respectively) plots. The smallest variability is found in the young plots were competition level is low and which have not or are in the early stages of the development of social classes, thus biomass partition being determined primarily by tree species characteristics. Conversely, adult stands where competition is stronger and social classes are already developed with some trees dominating others. These trends are also denoted by the significant differences between the structure classes (all, $\mathrm{p}<0.05$ ), except between ME and MM for stem $(W=400, p=0.3)$ and crown $(W=600, p=0.3)$ biomass.

Table 4: Descriptive statistics of stem and crown biomass per composition, structure and development stage classes (where $\mathrm{m}$ is the mean, SD the standard deviation, min the minimum, max the maximum and CV the coefficient of variation).

\begin{tabular}{|c|c|c|c|c|c|c|c|c|c|c|}
\hline \multirow{2}{*}{ Plot } & \multicolumn{5}{|c|}{ Stem Biomass } & \multicolumn{5}{|c|}{ Crown Biomass } \\
\hline & m & SD & $\min$ & $\max$ & $\mathrm{CV}$ & $\mathbf{m}$ & SD & $\min$ & $\max$ & $\mathrm{CV}$ \\
\hline Pure & 58.2 & 14.3 & 28.4 & 84.8 & 25 & 41.8 & 14.3 & 15.2 & 71.6 & 34.2 \\
\hline Mixed & 68.1 & 13.7 & 40.3 & 84.7 & 20 & 31.9 & 13.7 & 15.3 & 59.7 & 43 \\
\hline Even-aged & 58.4 & 13.6 & 34.8 & 80.9 & 23 & 41.6 & 13.6 & 19.1 & 65.2 & 32.8 \\
\hline Multiaged & 62.1 & 15.1 & 28.4 & 84.8 & 24 & 37.9 & 15.1 & 15.2 & 71.6 & 40 \\
\hline Adult & 61.4 & 15.4 & 28.4 & 84.8 & 25 & 38.6 & 15.4 & 15.2 & 71.6 & 39.9 \\
\hline Young & 57.6 & 5.5 & 49.9 & 70.6 & 9.6 & 42.4 & 5.5 & 29.4 & 50.1 & 13 \\
\hline
\end{tabular}



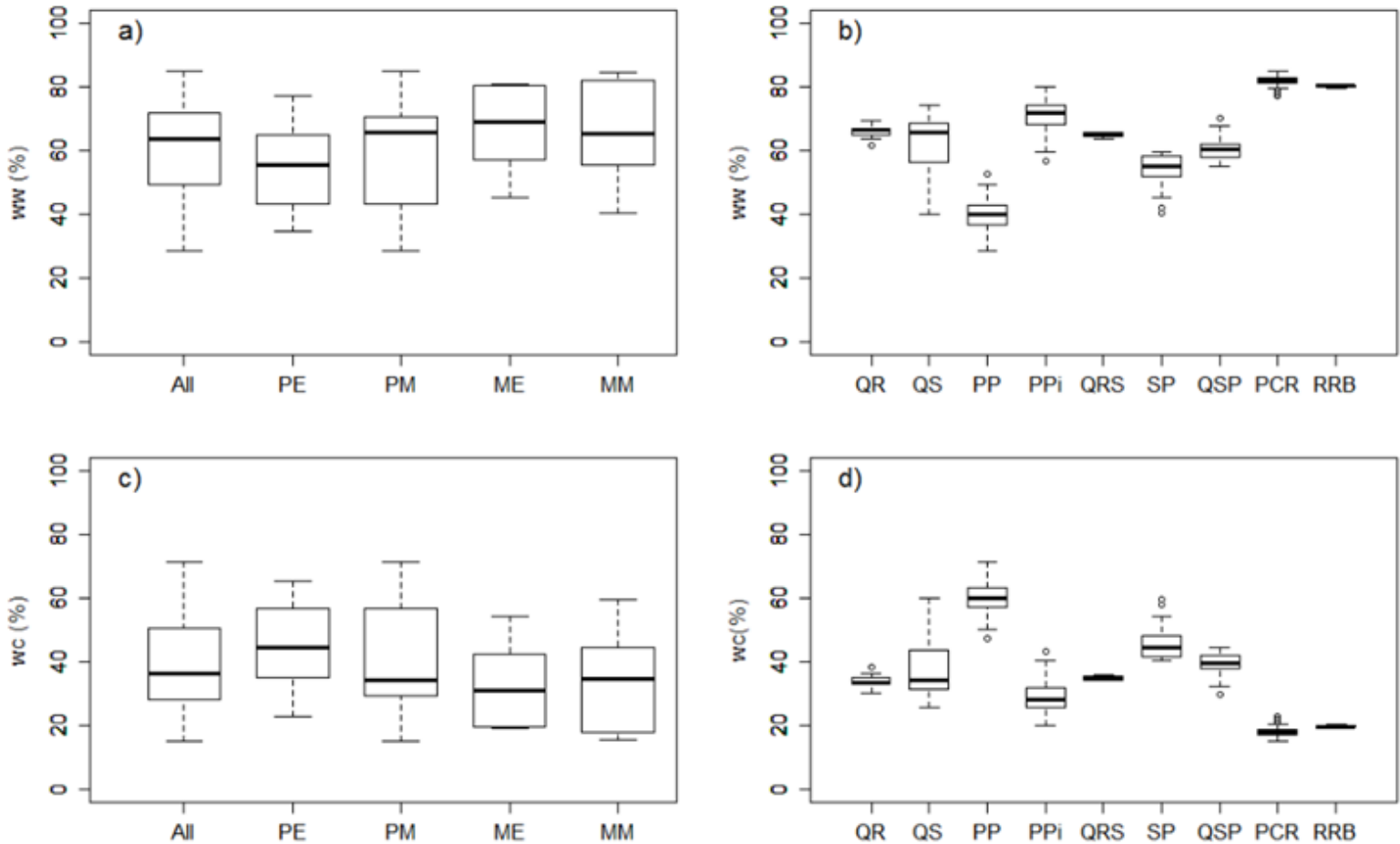

Figure 2: Boxplot of stem (ww) and crown (wc) biomass proportion for all plots, per structure classes $(a, c)$ and per composition classes (b,d).

Further details can be attained when plots are analysed per composition classes. In general, stem biomass increases from agro forestry systems (QR, QS, PP, QRS, SP, SPP) to stands managed for timber ( $\mathrm{PPi}, \mathrm{PCR}, \mathrm{RRB}$ ), while the inverse is observed for crown biomass (Table 5 and Figure $2 b, c$ ). This is mainly due to stand management options. Agro forestry systems focus their management on bark and/or fruit production, thus promoting stem and crown diameter growth and trees with relatively short stems, frequently forked [22]. Contrariwise, in stands managed for timber the management focus is attaining a high straight stems, free of branches that optimise timber volume. The structure indices such as hd ratio, linear crown ratio and crown ratio $[23,24]$ can bring some insights towards the understanding of the differences between the two stand types. Stands managed for timber when compared with agro forestry systems have higher hd ratio and crown ratio and lower linear crown ratio [25], in general resulting in a lower proportion of crown biomass in the former. These differences are corroborated by the significant differences of stem and crown biomass between the stands managed as agro forestry (QR, QS, PP, QRS, SP, SPP) and those managed for timber (PPi, PCR, RRB) (all, $\mathrm{p}<0.05)$. Yet, large variability is found for QS, PPi and PP. For the first two the dispersion can be explained by the development stages of the plots (young $v s$ adult) and for the latter due to the proportion of species and individuals per cohort [24-31].

Table 5: Descriptive statistics of stem and crown biomass per composition class (where $\mathrm{m}$ is the mean, SD the standard deviation, min the minimum, max the maximum and CV the coefficient of variation).

\begin{tabular}{|c|c|c|c|c|c|c|c|c|c|c|}
\hline \multirow{2}{*}{$\begin{array}{c}\text { Composition } \\
\text { Class }\end{array}$} & \multicolumn{9}{|c|}{ Stem Biomass } & \multicolumn{4}{c|}{ Crown Biomass } \\
\cline { 2 - 13 } & $\mathbf{m}$ & SD & $\mathbf{m i n}$ & $\mathbf{m a x}$ & $\mathbf{C V}$ & $\mathbf{m}$ & $\mathbf{S D}$ & $\mathbf{m i n}$ & $\mathbf{m a x}$ & $\mathbf{C V}$ \\
\hline QR & 65.9 & 1.8 & 62 & 69.6 & 2.7 & 34.1 & 1.8 & 30.4 & 38.2 & 5.2 \\
\hline QS & 62.9 & 7.5 & 40 & 74.5 & 12 & 37.1 & 7.5 & 25.5 & 59.9 & 20.3 \\
\hline PP & 40.1 & 4.7 & 28 & 52.8 & 11.8 & 59.9 & 4.7 & 47.2 & 71.6 & 7.9 \\
\hline PPi & 70.6 & 5.2 & 57 & 80 & 7.4 & 29.4 & 5.2 & 20 & 43.1 & 17.8 \\
\hline QRS & 65 & 0.8 & 64 & 65.9 & 1.3 & 35 & 0.8 & 34.1 & 36.1 & 2.4 \\
\hline SP & 53.8 & 5.4 & 40 & 59.7 & 10 & 46.2 & 5.4 & 40.3 & 59.7 & 11.6 \\
\hline SPP & 61.1 & 5 & 55 & 70.3 & 8.2 & 38.9 & 5 & 29.7 & 44.7 & 12.8 \\
\hline PCR & 82 & 1.8 & 77 & 84.8 & 2.2 & 18 & 1.8 & 15.2 & 22.8 & 10 \\
\hline RRB & 80.3 & 0.5 & 80 & 80.9 & 0.6 & 19.7 & 0.5 & 19.1 & 20.5 & 2.3 \\
\hline
\end{tabular}




\section{Conclusion}

Forest trees ecological characteristics determine the proportion of stem and crown biomass, particularly if they are in free growth. However, stand structure plays a key role on the above-ground biomass proportions. Composition, structure, stage of development and spatial arrangement, both horizontal and vertical, encompass a suite of interactions between individuals in a stand resulting in a wide range of variation of stem and crown biomass proportions per stand.

In general, crown biomass proportion is larger for species with wider crowns, weak epinastic control, shade tolerant and in free growth. At stand level crown biomass is larger for stands managed as agro forestry systems, especially those in the adult stage of development, while for stands managed for timber stem biomass proportion is larger. Overall stem biomass increases from pure to mixed, from even-aged to multiaged and from young to adult stands, while for crown biomass the opposite is observed.

\section{Acknowledgement}

The work was financed by National Funds through FCTFoundation for Science and Technology under the Project UID/ AGR/00115/2013.

\section{References}

1. Mc Roberts R, Tomppo E, Naesset E (2010) Advanced and emerging issues on national forest inventories. Scandinavian Journal of Forest Research 25: 368-381.

2. Tomppo E, Haakana M, Katila M, Peräsaari J (2008) Multi-source national forest inventory-Methods and applications. Managing Forest Ecosystems 18, Dordrecht, The Netherlands.

3. Brown S, Gillespie AJR, Lugo AE (1989) Biomass estimation methods for tropical forests with applications to forest inventory data. For Sci 35(4): 881-902.

4. Eamus D, Mc Guinness K, William B (2000) Review of Allometric Relationships for Estimating Woody Biomass for Queensland, the Northern Territory and Western Australia. Australian Greenhouse Office, Canberra, Australia $56 \mathrm{pp}$.

5. Jenkins JC, Chojnacky DC, Heath LS, Birdsey RA (2003) National-scale biomass estimators for United States tree species. For Sci 49(1): 12-35.

6. Arias D, Calvo-Alvarado J, Richter D de B, Dohrenbusch A (2011) Productivity, aboveground biomass, nutrient uptake and carbon content in fast-growing tree plantations of native and introduced species in the Southern Region of Costa Rica. Biomass Bioenergy 35(5): 1779-1788.

7. Egnell G (2017) A review of Nordic trials studying effects of biomass harvest intensity on subsequent forest production. For. Ecol. Manag 383: $27-36$

8. Belleau A, Brais S, Paré D (2006) Soil Nutrient Dynamics after Harvesting and Slash Treatments in Boreal Aspen Stands. Soil Sci Soc Am J 70(4): 1189-1199.

9. Achat DL, Deleuze C, Landmann G, Pousse N, Ranger J, et al. (2015) Quantifying consequences of removing harvesting residues on forest soils and tree growth e a meta-analysis. For Ecol Manag 348: 124-141.

10. Assmann E (1970) The principles of forest yield study. Pergamon Press, Oxford, UK, 506 pp.
11. Avery TE, Burkhart HE (1994) Measurements. ( $4^{\text {th }}$ edn.) Macgraw-Hill, Inc, New York, USA. 408 pp.

12. Gonçalves AC (2017) Multi-species stand classification: definition and perspectives. In: Chakravarty S, Shukla G (Editors), Forest Ecology and Conservation, InTech, Rijeka, Croatia, 4-23 pp.

13. Correia AC, Faias S, Tomé M, Evangelista M, Freire J, et al. (2008) Ajustamento simultâneo de equações de biomassa de pinheiro manso no Sul de Portugal [Simultaneous fitting of equations for umbrella pine biomass in the south of Portugal]. Silva Lusit. 16(2): 197-205 [in portuguese].

14. Carvalho JP (2003) Uso da propriedade da aditividade de componentes de biomassa individual de Quercus pyrenaica Willd. com recurso a um sistema de equações não-linear [Use of individual biomass component additive properties of Quercus pyrenaica Willd. Using a non-linear equation system]. Silva Lusit 11(2): 141-152 [in portuguese].

15. Gonçalves AC, Oliveira AC (2011) Regeneration in multi-species in Serra da Lousã. Forest Systems 20(3): 444-452.

16. Humphries CJ, Press JR, Sutton DA (1989) The Hamlyn guide to trees of Britain and Europe. Hamlyn Publishing Group Ldt, London, UK 325 pp.

17. Gonzalez GL (1982) La Guia de INCAFO de los arboles y arbustos de la Peninsula Iberica [INCAFO guide of the trees and shrubs of Iberian Peninsula]. INCAFO, Madrid, Spain, 866 pp [in spanish].

18. Correia AV, Oliveira AC (1999) Principais espécies florestais com interesse para Portugal: zonas de influência mediterrânica [Main forest species with interest for Portugal: zones of Mediterranean influence]. Direcção-Geral das Florestas, Lisboa, Portugal 119 pp [in portuguese].

19. Correia AV, Oliveira AC (2003) Principais espécies florestais com interesse para Portugal: zonas de influência atlântica [Main forest species with interest for Portugal: zones of Atlantic influence]. Direcção-Geral das Florestas, Lisboa, Portugal. 187 pp. [in portuguese]

20. Ferreira AG, Gonçalves AC, Pinheiro AC, Gomes CP, Ilhéu M, et al. (2001) Plano específico de ordenamento florestal para o Alentejo [Specific Forest Planning Plan for Alentejo]. Universidade de Évora, Évora, Portugal.

21. Diaci J, Kerr G, O'Hara K (2011) Twenty-first century forestry: integrating ecologically based, uneven-aged silviculture with increased demands on forests. Forestry 84(5): 463-465.

22. Correia AV, Oliveira AC (1999) Principais espécies florestais com interesse para Portugal: zonas de influência mediterrânica [Main forest species with interest for Portugal: zones of Mediterranean influence] Direcção-Geral das Florestas, Lisboa, Portugal. 119 pp [in portuguese].

23. Hasenauer H (1997) Dimensional relationships of open-grown trees in Austria. For. Ecol. Manag 96(3): 197-206.

24. Gonçalves AC, Oliveira AC, Dias SS (2010) Evolution in multi-species high forest stands in Serra da Lousã: Diversity analysis. Silva Lusit. $n^{0}$ especial: 79-90.

25. Gonçalves AC (2018) Effects of Forest Stand Structure in Biomass and Carbon. In: Shukla G (Editor.), Forest Biomass and Carbon, InTech, Rijeka, Croatia.

26. Fehrmann L, Kleinn C (2006) General considerations about the use of allometric equations for biomass estimation on the example of Norway spruce in central Europe. For. Ecol. Manag. 236(2-3): 412-421.

27. de Jong J, Akselsson C, Egnell G, Löfgren S, Olsson BA (2017) Realizing the energy potential of forest biomass in Sweden - How much is environmentally sustainable? For. Ecol. Manag. 383(1): 3-16.

28. Correia AV, Oliveira AC (2003) Principais espécies florestais com interesse para Portugal: zonas de influência atlântica [Main forest species with interest for Portugal: zones of Atlantic influence]. Direcção-Geral das Florestas, Lisboa, Portugal. 187 pp. [in portuguese]. 
29. Djomo AN, Ibrahima A, Saborowski J, Gravenhorst G (2010) Allometric equations for biomass estimations in Cameroon and pan moist tropical equations including biomass data from Africa. For. Ecol. Manag. 260(10): 1873-1885.

30. Henry M, Picard N, Trotta C, Manlay RJ, Valentini R, et al. (2011) Estimating Tree Biomass of Sub-Saharan African Forests: a Review of Available Allometric Equations. Silva Fennica 45(3B): 477-569.
31. IFN5 (2010) Inventário Florestal Nacional. IFN5 2005-2006 [National Forest Inventory. IFN5 2005-2006]. Auto ridade Florestal Nacional, Lisboa, Portugal, 209 pp. [in Portuguese].

\section{Your next submission with Juniper Publishers will reach you the below assets}

This work is licensed under Creative

Commons Attribution 4.0 License

DOI: 10.19080/JOJHA.2018.01.555565
- Quality Editorial service

- Swift Peer Review

- Reprints availability

- E-prints Service

- Manuscript Podcast for convenient understanding

- Global attainment for your research

- Manuscript accessibility in different formats

( Pdf, E-pub, Full Text, Audio)

- Unceasing customer service

Track the below URL for one-step submission https://juniperpublishers.com/online-submission.php 